(6,900 words)

ENLIGHTENING COMMUNICATION ANALYSIS IN ASIA-PACIFIC:

Media Studies, Ethics and Law using a Buddhist Perspective

\title{
Mark Pearson
}

* Mark Pearson is Professor of Journalism and Social Media in the School of Humanities at Griffith University, Australia and a member of the Griffith Centre for Cultural Research and its Socio-Legal Research Centre. He is co-author (with Mark Polden) of The Journalist's Guide to Media Law - A handbook for communicators in a digital world (5th Ed, Allen \& Unwin, Sydney, 2015) and co-editor (with Shelton A. Gunaratne and Sugath Senarath) of Mindful Journalism and News Ethics in the Digital Era: A Buddhist Approach (Routledge, London and NY, 2015). The author gives heartfelt thanks to the editor Professor Shelton A. Gunaratne for his wise counsel and to the reviewers for their valuable input.

\footnotetext{
Abstract

A Western paradigm has dominated approaches to communication and journalism studies particularly in the areas of theory, analysis, and law and ethics. This article backgrounds important critiques of that paradigm, and considers how globalized communication and media studies has become, before exemplifying how a secular Buddhist perspective might offer 2,500 year-old analytical tools that can assist with media analysis, law and ethics. The article proposes the Buddha's Four Noble Truths and their associated Noble Eightfold Path
} 
(magga) can be fruitful tools for informing communication theory and analysis, and media law and ethics. The article begins by assessing the extent to which communication and media studies in Asia and the Pacific has shifted to accommodate non-Western approaches. In media analysis, it suggests the Buddha’s teachings on Right Speech (samma vaca) offer key understandings to assist with the deconstruction of media texts. In media law and ethics, it extends the application of Right Speech principles to comparing defences to libel (defamation) as they have developed in four Western jurisdictions.

\section{Keywords}

Communication theory, mindful journalism, communication ethics, media law, communication ethics, communication law, Buddhism, defamation, libel, First Amendment

\section{Introduction}

The Western paradigm that has dominated approaches to communication and media studies over recent decades might, as Gunaratne (2015) suggests in his lead article in this issue, benefit from a more globalized perspective, particularly one allowing for traditions like Buddhism that have been theorizing communication for more than two millennia. Gunaratne (2015) argues for a "humanocentric enterprise covering the seminal philosophies of all humanity”. This article draws upon some key Buddhist principles that might be utilized by globalized scholars in a secular way to enhance their current approaches to communication studies in the areas of theory, analysis, ethics and law. It begins with a short consideration of 
the extent to which communication and media studies in the Asia-Pacific region has accommodated alternative perspectives drawing upon Wang’s (2014) commensurability/ incommensurability (C/I) framework as an analytical focus. Wang posited an insightful argument for the application of regionally originated and focused geocultural theories to be broadened for international application, concluding

The C/I framework aims at facilitating exchanges and communication across paradigmatic boundaries and theory development following a dynamic paradigm, but whether there are perceived needs for such exchanges, and whether ideas and opportunities made available are recognized as such, and appreciated and taken advantage of, are entirely different matters. It is hoped that the C/I framework can be a starting point for concerted efforts in the future-if academic communities in both the Western and the non-Western world agree on the significance of dialogue and exchanges. (p. 388)

This article then exemplifies how one non-Western approach might work in practice by demonstrating how core Buddhist principles might:

- $\quad$ assist with the analysis of media talk by using the Buddha's teachings on Right Speech (samma vaca) to help reach understandings to interpret media texts;

- extend the application of Right Speech (samma vaca) principles to critiquing First Amendment defences to libel (defamation), born of a libertarian tradition;

- offer a theory of media analysis showing features of commensurability rather than universality in its application. 
These goals are ambitious, and the article aims only to offer an indication of what might be achieved in extended studies devoted solely to each of these topics.

\section{Need for a more globalized approach in the Asia-Pacific}

The extent to which communication studies in Asia and the Pacific region has accommodated more globalized (or less Westernized) approaches is worthy of a study in its own right. It deserves a detailed analysis across a range of criteria including meta-analyses of journal articles by Asia-Pacific scholars and about Asia-Pacific communication, citations of articles and scholars offering alternative perspectives, international rankings of Asia-Pacific based communication and media journals, and a systematic account of the curricula of communication and media tertiary courses in the region to ascertain the extent to which Asian, indigenous and other theoretical perspectives have been accommodated in readings and teaching schedules.

Another indicator worthy of attention is the representation of leading scholars of nonWestern background in the academy. There can be little argument that there is a globalized academy in the field of communication and media, but analysis of the traditions practised in their work is more challenging.

It is important to conduct any such analysis within a sound theoretical structure, and Wang's (2014, p. 385) commensurability/ incommensurability (C/I) framework for geocultural theories is a useful tool. Wang (2014, p. 374) contrasted the C/I model with the universality/particularity model (the U/P model) and proceeded to identify shortcomings with geocultural theories stemming from a strict 'local' application, including the difficulty in finding a universal application for their application and the fact that the very notion of theory 
building and academic research enterprise is so firmly entrenched in post-Enlightenment Western thought. The commensurability approach, however, challenges this dichotomy by suggesting Eastern and other traditions might form part of communication theory by having commonality and utility, perhaps in partnership with the European dialectic method (p. 375). Drawing upon such an approach, it is possible to make some observations about selected aspects of Asia-Pacific communication studies.

In the field of publishing and the academic enterprise, it appears there is a strong focus on the 'local' that is 'particular' to the region rather than upon the exploration and application of Asia-Pacific theory-generation with universal application. Thus, for example, journals might carry an Asian or Pacific name in their title (for example, Asian Journal of Communication or Pacific Journalism Review), but such nomenclature ordinarily signifies the articles are by scholars from that part of the world or report upon communication and media research into topics in that geographical region - typically using the European dialectic approach. The narrower geographical focus might be one factor in such journals being less well regarded in international publishing rankings. One quantifiable example of the regard for non-Western journals can be found in Australia. The Australian Research Council published rankings of international academic journals across all disciplines as part of its Excellence in Research for Australia (ERA) initiative. Of the 123 journals ranked under its Communication and Media Studies field of research number 2001, five obtained the highest ranking of A*, 45 were assigned A, 73 were at B level and 28 obtained the lowest ranking of C. No geographically specific journals earned a place in the A* category, while only two were ranked A - the Asian Journal of Communication and Inter-Asia Cultural Studies (Lampe, 2010). That is not to say researchers from developing countries have not been successful in 
being published in top international communication and journalism journals. However, the large majority have done so by adopting traditional Western career paths, often via doctoral and post-doctoral work in North American or European universities, citing Western communication theories and scholars and collaborating with European or American colleagues. That is not to say the application of non-Western approaches is a terra nullius. There have been notable exceptions over many years in both books and articles in leading journals. Examples include Gunaratne in Media, Culture and Society (2010) and Wang and Shen (2000) in the Asian Journal of Communication.

There have also been historic attempts to engage a more diverse international range of approaches in the communication and media field, led by edited collections such as those by Servaes, Jacobson and White (1996), Curran and Park (2000) and Christians and Nordenstreng (2014) focusing on communication and media studies and issues in a large range of geographical locations, including chapters on the need to break through the Westernized paradigm. However, even in such works the scholarship adopts a predominantly Western paradigm to bemoan the Eurocentric nature of communication studies. Two notable exceptions were chapters by Faniran (2014) and Kumar (2014), which advanced alternative approaches to communication research drawing upon cultural and philosophical traditions in Africa and Asia. Faniran (2014: 146-8) posited key features of the communalistic cultures of Africa as functional non-Western lenses for examining communication in that continent, while Kumar explored diverse approaches within Indian theories of communication to demonstrate the value of applying lenses from a range of "historical, religious-spiritual and literary” perspectives (Kumar, 2014: 172). 
The issue has been revisited in a refreshing way in the special issue of Communication Theory re-assessing the de-Westernization of communication studies, where editors Waisbord and Mellado (2014: 361) noted:

Scholars have urged colleagues to be loyal to local values, cultivate a regional mindset and academic spaces, and rethink conventional Western categories and arguments from indigenous perspectives ... This line of criticism is present in arguments to abandon Western notions of democracy, public sphere, journalism in the study of local communication processes for those ideas are premised on foreign notions of agency and personhood.

Two useful examples of the application of Chinese religious and cultural traditions to communication analysis have been published in the Chinese Journal of Communication. In the field of communication law, Han (2010: 344-5) drew upon historical, political and cultural approaches to cultural commodification to present important insights into Chinese approaches to intellectual property and argued private control over cultural products was not alien to Chinese tradition, as has so often been portrayed. Li and Witteborn (2012) engaged with Confucian values and practices to critique the 22-episode revolutionary history television drama from 2002, In Those Passionate Days. They demonstrated how key Confucian values of benevolence, qing and filial piety engaged the audiences despite the fact that many were of a Communist generation widely perceived as being apolitical and 
individualistic (p. 161). Thus, we see the use of non-Western cultural values providing a moral backbone to communication analysis in an Asian context.

In media ethics, there have been new forms of analysis and guidance to journalism practice emerging from a rejection of a pure libertarian approach to journalism and the role of the media. Such approaches include peace journalism (Galtung \& Ruge, 1965; Lynch, 2010; Lynch, 2005; Lynch \& Galtung, 2010); its extension to other cultures by Robie (2011 \& 2014); civic engagement (Rosen, 1999; Romano, 2010); slow journalism (Le Masurier, 2015) and inclusive journalism (Rupar \& Pesic, 2012). While offering a strongly ethical perspective, they do not adopt a specific non-Western framework in their analysis of media practice and their recommendations of globalized alternatives. Rather, as argued by Gunaratne (2005: 81-82), they are in fact anchored in Western philosophical traditions but operate from a position of problematic practices inherent in the modern U.S. and British news media models and posit more inclusive and caring alternatives. It could be argued they implement a 'social responsibility' model to their approaches, affording a social conscience perspective not found in the 'libertarian’, ‘Fourth Estate’ tradition with U.S. First Amendment-driven media as an exemplar (Hutchins, 1947).

The 'mindful journalism' approach of Gunaratne, Pearson and Senarath (2015) adopts the ethical tenets of a particular tradition - Buddhism - as a framework for a new moral compass to both analyse news media practice and to guide the professional decisions of journalists who might lack one. It is this latter approach that is used in this article as a device to offer an alternative reading of media analysis and ethics. 


\section{Tenets of Right Speech in the analysis of 'Media Talk'}

Over the past two decades the branch of media studies known as 'Media Talk' has used discourse and conversation analysis to offer insights into the language used in news, talkback, interviewing programs, sports, by radio disc jockey and in reality programming on radio and television, pioneered by Andrew Tolson (2006). Tolson's use of the term media talk in the title of his seminal work in the field and development of its methodologies has led to a discrete branch of communication studies using meticulous analysis of language in the media to inform analysis. The techniques have added significantly to the body of communication literature with findings that offer important new ways of looking at the interplay between language, media, production, culture and audiences.

However, the approach lacks an ethical dimension, which can be gained using a humanocentric approach drawing upon systems methodology (Gunaratne, 2005). Value can be added to such analysis when an application of the Buddhist ethic of Right Speech is added to the analysis of media talk by communication professionals.

The path of Right Speech (samma vaca) was one of eight interdependent steps in Buddha's Eightfold Path to enlightenment, which he foreshadowed in his Four Noble Truths as the path (magga) to escape suffering (dukkha) caused by fetters like desire (tanha) and attachment (upadana). Along with Right Action (samma kamanta) and Right Livelihood (samma ajiva), Right Speech forms part of the sila (ethical conduct) dimension of the Eightfold Path. A fundamental Buddhist tenet is that an ethical principle like Right Speech is inextricably linked with other key elements of the Buddhist framework including the principles that life is impermanent (anicca), unsatisfactory (dukkha) and nonsubstantial (anatta); and that one’s actions such as speech have an impact upon both one’s self and others (kamma). 
A key consideration in their commensurability is that, as Bhikkhu Bodhi (1998) explains, the main goal of the ethical dimension of sila is a spiritual one, although this article proposes it might be used as a functioning framework for communication analysis. Communication scholars including Dissanayake (2003: 31-2) and Miike (2014: 124) have already flagged the potential for Right Speech being utilized in a theoretical context. Dissanayake (2003) described Right Speech as 'One of the cardinal tenets guiding the moral life of a Buddhist ... linked to the concept of verbal communication enunciated in Buddhism.'

Right Speech offers a useful theoretical framework by which to analyse Media Talk. In his book, Tolson (2006: 3) places his focus firmly on "conversational media talk - primarily in broadcast media - which either addresses the audience directly, or attempts to engage the audience in quasi-interactive relationships.” An alternative yet mindful analysis of media talk can add value to such an approach by exploring the potential application of the Buddhist ideal of Right Speech to a journalism and social media context. It allows analysis to go beyond broader radio and television dialogue and focus on the moral and ethical dynamic of communication in the Web 2.0 news and social media context. To that end, there is some overlap with Tolson's news talk material (2006: 57), although it involves more discussion of models for the ethical approaches of news practitioners to their interviewing and the language of reporting rather than engaging in a comprehensive discourse analysis of those outputs.

It becomes a different kind of discourse analysis when we begin to examine excerpts of media dialogue and consider them in the context of Right Speech adding an ethical dimension to the analysis. Given the constraints of space and time, we will only highlight two brief examples here - from radio and online media. 
Example 1: The 2DAYFM royal prank call episode

A surreptitious prank call recording by DJs Mel Greig and Michael (MC) Christian on Sydney's 2DAYFM in 2012 made international news when they managed to get connected through to a nurse in a London hospital who was caring for the Duchess of Cambridge, then suffering morning sickness during her pregnancy with Prince George. The DJs put on voices purporting the Queen and Prince Charles. The global prank turned sour when the duty nurse who had connected the call through to the ward committed suicide and left a note blaming the humiliation of the episode for her despair. The Australian Communications and Media Authority (ACMA) launched an investigation into whether the radio station had breached a condition of its license prohibiting it from breaking the law, in this case the Surveillance Devices Act 2007 (NSW) (Today FM (Sydney) Pty Ltd v Australian Communications and Media Authority [2013] FCA 1157. ). The ACMA’s authority to make such a ruling was questioned in a High Court appeal, which found it did indeed have the power to rule that a station's behaviour had been criminal even though this had not been proven in a court: Australian Communications and Media Authority v Today FM (Sydney) Pty Ltd [2015] HCA 7, 4 March 2015 S225/2014.

The basic premise of the prank call is to exploit the naivety, trust, and vulnerability of the target for the entertainment of the listener. A prank call typically involves a family member, friend or work colleague contacting the radio station to set the target up with some information about something they know has upset them and will likely trigger a reaction. By definition, the individual is already vulnerable in some way - frustrated by bureaucracy, 
upset over a relationship, feeling guilty about some trivial misdemeanour, or just known to be gullible and an easy target. So would the prank call have passed the Right Speech test if 2DAYFM personnel were mindful enough to apply it before recording it, or even later before broadcasting it? We could work our way through all of the listed attributes; but, for the sake of the exercise, we will simply look to the Buddha's six criteria from his Abhaya Sutta on Right Speech, and we will find immediately that this episode failed the very first:

[1] In the case of words that the Tathagata knows to be unfactual, untrue, unbeneficial (or: not connected with the goal), unendearing \& disagreeable to others, he does not say them. (Thanissaro, 1997)

Indeed, the prank call concept is premised on the introductory guise being untrue and, while one could find benefits in bringing the humour of laughing at the expense of others to some members of the audience, it is indeed unbeneficial, unendearing and disagreeable to the target of the call. And in this case it had tragic consequences. Using the schema alone the call would have been ruled out. Of course many other factors would have played into this from the Right Speech category and other steps in the Path, most notable Right Intent. Given the topic of the prank was the royal family, it raises the issue of the extent to which celebrity gossip-style journalism would be sustainable under a Right Speech approach. The simple answer is that it would not. It would fall foul of the Buddha's disapproval of gossipmongering, summed up best in the Saleyyaka Sutta (Nanamoli, 1994):

He is a gossip: as one who tells that which is unseasonable, that which is not fact, that which is not good, that which is not the Dhamma, that which is not the Discipline, and he speaks out of season speech not worth recording, which is unreasoned, indefinite, and unconnected with good. 
Other key Buddhist tenets figure prominently in this case study - most obviously suffering (dukkha) and the consequential impacts of one's speech and actions upon others (kamma), particularly given the tragic consequences of the call and the ongoing suffering for families and the DJs themselves.

Such an analytical tool can be applied quite separate from the regulatory processes of a bureaucratic entity like the Australian Communications and Media Authority and without the need for a High Court appeal ruling on the topic. For the purposes of communication ethics analysis, this Right Speech approach achieves the same result but in a much speedier and understandable way for communication professionals and ethical theorists to access and apply.

Example 2: Publishing offensive online speech-The Perth Now case.

A West Australian case centred upon racist comments on News Corporation's Perth Now website about indigenous youths who had died in a car accident. The following is a selection of comments seen and approved by a moderator:

'...until these young people gain the respect and gratitude of all races then they will continually be thought of as violent and criminals, can't keep using the same excuse forever, everyone else has to gain the publics [sic] respect, why in the hell should that exclude aboriginals?'

'...now 'the elders grieve'. Where were they when the little kids needed supervision late at night’ RIP criminal and poor little boys.' 
'...criminal trash like these young boys'

'Let em [sic] all fight and kill each other i [sic] say!' (Clarke v Nationwide News Pty Ltd trading as The Sunday Times [2012] FCA 307).

This is the nature of racist online commentary in the new era - and the news media cannot be held responsible for what ordinary citizens are saying on social media. However, these were moderated comments posted to the website of a Murdoch-owned mainstream newspaper. An important issue is the media outlet's responsibility for the comments of others on its products. In Australia, following Australian Competition and Consumer Commission (ACCC) v Allergy Pathway Pty Ltd and Anor (No 2) [2011] FCA 74, the publisher is held responsible for the comments of third parties on their websites and social media platforms they control. So, legally the media company was held responsible for the racially discriminatory comments it hosted here. The Federal Court ordered the publisher to pay the boys' mother \$12,000 compensation for her humiliation under the Racial Discrimination Act.

Under the Right Speech schema the repeating of the wrongful speech of others is unacceptable under Buddhist doctrine, as detailed in the Saleyyaka Sutta (Nanamoli, 1994): He speaks maliciously: he is a repeater elsewhere of what is heard here for the purpose of causing division from these, or he is a repeater to these of what is heard elsewhere for the purpose of causing division from those, and he is thus a divider of the united, a creator of divisions, who enjoys discord, rejoices in discord, delights in discord, he is a speaker of words that create discord. 
Two categories under the schema might apply, given the impossibility of proving the fact or truth of opinions.

[2] In the case of words that the Tathagata [the Buddha] knows to be factual, true, unbeneficial, unendearing \& disagreeable to others, he does not say them.

[3] In the case of words that the Tathagata knows to be factual, true, beneficial, but unendearing \& disagreeable to others, he has a sense of the proper time for saying them. (Thanissaro, 1997)

Most of the comments would surely be unendearing and disagreeable to others, and most should be considered unbeneficial; however, some argue there should not be censorship of debates over race. Australia has recently endured such a debate over section 18C of its Racial Discrimination Act, which was at issue in this case. However, even if some might argue the airing of such views is beneficial, nobody could argue that the 'sense of the proper time' criterion was met by the newspaper publishing such demeaning comments on the eve of the boys' funeral.

Again, the Right Speech schema provides an ethical dimension to an analysis of media talk that the standard Tolson (2006) approach of using discourse and conversation analysis might not. The mindful journalism approach to framing media ethical practices - particularly the step in the Eightfold Path known as Right Speech - offers both a theoretical/ethical framework for analyzing media talk as well as some actual techniques professional communicators might adopt to avoid some of the many pitfalls in news media discourse. From these two short examples it is evident that a Right Speech schema applied in a media talk context can offer media ethics researchers a useful schema by which to weigh the 
morality of reporting in journalism and Web 2.0 professional communication.

\section{Media law: Christian origins of defamation and a Buddhist alternative}

The ultimate contest over media talk and Right Speech happens in the courts when media texts face charges for their criminality or are the subject of civil suits over their alleged infringement on citizens' rights like copyright, confidentiality and defamation. There is also value in applying a mindful, Buddhist approach to the study of communication and media law. We can hardly reject the teachings of the founder of one of the world's greatest religions as inappropriate in a communication law context on exclusively secular grounds because that would imply our so-called secular approaches to communication and media theory and ethics have no religious roots. No Western academic could deny deep-seated Abrahamic influences upon the cultural origins of media law and its scholarship. A whole body of literature on the philosophy of science and religion attests to it. In media law and ethics, libertarian approaches to press freedom espoused by the likes of Milton, Mill and Jefferson arose in an era when political, cultural and religious notions of rights were intertwined. For example, the most famous treatise against licensing of the press - Milton’s Areopagitica - was prefaced with an explanation that Moses, David and Paul the Apostle were all learned because they were able to read widely. Milton wrote:

... as good almost kill a Man as kill a good Book; who kills a Man kills a reasonable creature, Gods Image; but hee who destroyes a good Booke, kills reason it selfe, kills the Image of God, as it were in the eye (Milton, 1644). 
The U.S. Supreme Court cited Areopagitica in the landmark defamation case of New York Times v. Sullivan (1964) 376 US 254, when explaining why it would be counter-productive to move the burden of proving truth to the defendant (NY Times v. Sullivan, Footnote 19). Thus, by only two degrees of separation, we find Judeo-Christian teachings informing a key decision on news media talk in one of the most purportedly secular of institutions - the U.S. Supreme Court. Related to this, as Rolph (2008: 38-43) notes, defamation as the tort used to contest objectionable speech, first arose in England in 1222 in the ecclesiastical (church) courts where it remained a spiritual offence for about four centuries. Damage to a reputation was seen to be an offence to the target's soul - a right that only God should possess - to be judged only by God’s earthly adjudicators, the clergy. There was even recourse for appeals from English ecclesiastical court judgments to the Pope (Rolph, 2008: 45). From the $16^{\text {th }}$ century, defamation actions were increasingly brought in the common law courts, with the courts developing a list of allegations with which they would deal, without needing proof of actual damage being caused by the defamation (Morison \& Sappideen 1989: 173). Even today the Catechism of the Catholic Church lists ‘detraction’ (essentially gossip - or disclosing 'another's faults and failings to persons who did not know them') as a sin - or an 'offense against truth' (Catechism of the Catholic Church, para 2477). Thus, defamation action - the legal action available to those subjected to damaging media talk - has a traceable Christian genealogy.

In this globalised, multi-cultural and multi-jurisdictional Web 2.0 era there should be no reason why the Judeo-Christian lens should have a monopoly on our examination of communication law. A mindful reading of defamation law benefits from a consideration of 
both Right Speech principles and concepts of necessary truth-telling. While it is far-fetched to expect judges and legislators in the West would turn to Buddhism for the reform of defamation law, an effort to abide by truth-telling and Right Speech principles could operate effectively when professional communicators are attempting to avoid libel litigation when pursuing their stories. Further, they present excellent tools for an alternative analysis. Analysis of the development of defamation defences in Canada, the UK, Australia and the U.S. benefit from a Buddhist reading. In Grant v. Torstar Corp., 2009 SCC 61, [2009] 3 S.C.R. 640, the Supreme Court of Canada developed a 'responsible communication' defence to defamation for matters which might not have been able to be proven absolutely as true, but were still diligently reported and were clearly in the public interest to be aired within the spirit of the Canadian Charter of Rights and Freedoms protection of free expression. Chief Justice McLachlin summed up the relevant factors of the 'responsible communication' defence on a demonstrable matter of public interest in these terms:

- seriousness of the allegation

- public importance of the matter

- urgency of the matter

- status and reliability of the source

- whether the plaintiff's side of the story was sought and accurately reported

- whether the inclusion of the defamatory material was justifiable

- whether a defamatory statement's public interest lay in the fact that it had been made rather than whether it was truthful

- other relevant circumstances 
The court drew upon similar criteria to those developed earlier in the UK case of Reynolds $v$. Times Newspapers Ltd [2001] 2 AC 127 as part of the common law qualified privilege defence and elements of the statutory qualified privilege defence in Australia's uniform Defamation Acts 2005.

The most significant First Amendment case in recent decades was New York Times v. Sullivan (1964) 376 US 254 where it was ruled that public officials had to meet tough new tests before they could succeed in a defamation action even if the allegations in the article were proven false. It established that plaintiffs who were 'public officials' had to prove a media defendant had acted with 'actual malice' if they were to win a defamation action, even if the defamatory allegation was untrue. The test has since been expanded to apply to any 'public figure' - essentially anyone who is well known to the public, has taken on some public role or who has participated voluntarily in some controversy. While the principle has some difficulties in definition and application, it has meant the media in the United States have been free to publish criticism of virtually anyone in the public domain, even if the criticism proves to be unfounded, just so long as they have not acted maliciously or in 'reckless disregard' of the truth.

It is possible to implement a Buddhist approach using the Right Speech teachings from the Noble Eightfold Path to conduct an analysis in this area of communication law. The author proposes to do this more thoroughly in future work. However, for the purposes of this argument we might return to the Abhaya Sutta cited earlier and contrast these defences as they have been developed in these jurisdictions (Thanissaro, 1997). Crucial to the Canadian 'responsible communication' defence and its qualified privilege cousins in the UK and Australia is the extent to which reporters and publishers honestly believe in the truth of the 
defamatory material published, even though they might not have the firm evidence to prove this in court. They would pass the Buddhist (mindful journalism) test if they had an honest belief the material was "factual, true, beneficial” while perhaps being "unendearing and disagreeable to others", as long as they had chosen the "proper time" for reporting it (Thanissaro, 1997). However, the U.S. defences driven by the First Amendment takes this liberty a step too far under this schema, because it allows unbeneficial, unendearing and disagreeable material to be published about public figures as long as it has not been done with malice. It also allows for untruthful gossip-mongering, as identified earlier in the Saleyyaka Sutta (Nanamoli, 1994) as ethically problematic. Such analysis shows promise in the field of media law analysis, reform and policy development because it provides a working ethical framework to apply to legislation and the fact scenarios of particular cases.

\section{Conclusion}

This article considered the extent to which communication and media studies in the AsiaPacific region has accommodated alternative perspectives drawing upon Wang’s (2014) commensurability/ incommensurability (C/I) framework as an analytical focus. It has found that while many scholars from the region have continued working within a European dialectic framework in their communication scholarship, there have been notable applications of alternative approaches drawing upon social responsibility frameworks and, refreshingly, some bold attempts to incorporate cultural communicative traditions into the development of communication theory and analysis. This lends credence to Wang's proposal for an imperfect commensurability model because communication scholarship, while often undertaken by scholars whose cultural and religious traditions offer great scope for application to 
communication theory and analysis, their research and scholarship has usually fitted comfortably within Western frameworks. As a demonstration of one alternative, the article suggested a 'mindful' approach to communication studies could offer an ethical and phenomenological framework for the approach to important areas of communication analysis, and exemplified this with its application to the analysis of news 'media talk' and an important principle of communication law - the public interest defence to defamation. Gunaratne (2015) has called for a "humanocentric enterprise covering the seminal philosophies of all humanity”. This article shows that a mindful application of key Buddhist principles (such as Right Speech) can enhance approaches to communication studies in the areas of theory, analysis, ethics and law. This is not to suggest that this is the only tradition offering utility as an alternative to Western models. Its application as a framework for communication analysis thus offers attributes of commensurability rather than laying claim to universality as an analytical tool. This is because the secular application of spiritual and translated concepts handed down via a culturally anchored oral tradition over two millennia has utility for communication analysis, while terminologies and applications will inevitably vary in their particularity as they shift from clerical to lay to theoretical application. Of course, some might claim the very attempt to transcend such geocultural and historical boundaries renders such application “Asiacentric” if Buddhist phenomenology is forced upon communication analysis or even "Eurocentric" if it is considered an insensitive appropriation of ancient spiritual tracts for globalized communication studies. As Miike (2007) stated: Communication theorizing in the local community and the global society ought to move beyond the dualistic thinking of provincial specificity versus universal applicability. Any theory has local resonance and may have global significance. More 
and more scholarly endeavors must be made to generate theories that can resonate fully with the local context and, at the same time, suggest their possible global implications” (p. 277).

Such a view sits well with Buddhist phenomenology. Like any other theory, Right Speech is subject to impermanence (anicca) because the constant geocultural and time-space variations applied to it deny it a static identity ( $a t t a)$, so while its application might offer some synergies and utility, the interaction of these factors will inevitably lead to unsatisfactoriness (dukkha), an inescapable feature of life and, thus, of all communication analysis. Right Speech offers a theory of media analysis showing features of commensurability rather than universality in its application. Others might suggest different models for the incorporation of Buddhist phenomenology into communication scholarship. Either way, this is fertile ground for innovation in communication theorizing and analysis in a globalized world.

\section{References}

Bodhi, Bhikkhu. (Trans.) (1998). The Noble Eightfold Path: The Way to the End of Suffering, Access to Insight (Legacy Edition). Available at http://www.accesstoinsight.org/lib/authors/bodhi/waytoend.html .

Christians, C. and Nordenstreng, K. (eds.) (2014). Communication theories in a multicultural world. New York: Peter Lang.

Curran, J. \& Park, M-J. (eds.) (2000). De-Westernizing Media Studies.. London: Routledge. Dissanayake, W. (2003). Asian approaches to human communication: Retrospect and prospect. Intercultural Communication Studies, 12(4), 17-37. 
Faniran, J. O. (2014). Toward a Theory of African Communication. In Christians, C. and Nordenstreng, K. (eds.). Communication theories in a multicultural world (pp. 146-159). New York: Peter Lang..

Galtung, J. \& Ruge, M. (1965). The structure of foreign news: the presentation of the Congo, Cuba and Cyprus crises in four foreign newspapers. Journal of International Peace Research 1: 64-90.

Gunaratne, S. A. (2005). The Dao of the press: A humanocentric theory. Cresskill, NJ: Hampton Press.

Gunaratne, S. A. (2009). A Buddhist view of journalism: Emphasis on mutual causality. Javnost-the Public 16 (2): 61-75.

Gunaratne, S. A. (2010). De-Westernizing communication/social science research: opportunities and limitations. Media, Culture and Society. 32 (3): 473-500.

Gunaratne, S.A. (2015). Globalizing communication/journalism, ending fragmentation within philosophy, and analyzing history as life-spans in Samsara. International Communication Gazette 77 (7): [pending]

Gunaratne, S., Pearson, M. \& Senarath, S. (2015). Mindful journalism and news ethics in the digital era: A Buddhist approach. New York \& London: Routledge. 
Hanh, T.N. (1998). The Heart of the Buddha's teaching. Transforming suffering into peace, joy and liberation. New York: Rider.

Han, D. (2010). Can I own my writings and sell them too? A brief history of copyright in China from the late Qing era to Mao’s China. Chinese Journal of Communication. 3(3): 329346.

Hutchins, R.M. (1947). A Free and Responsible Press. A General Report on Mass

Communication: Newspapers, Radio, Motion Pictures, Magazines and Books. [Report of the Commission on Freedom of the Press]. University of Chicago Press: Chicago.

Kumar, K. J. (2014). 'Theorizing About Communication in India. Sadharanikaran, Rasa, and other traditions in rhetoric and aesthetics’. In Christians, C. and Nordenstreng, K. (eds.) (2014). Communication theories in a multicultural world. (pp. 160-175). New York: Peter Lang.

Lampe, J. (2010). ERA Journal Rankings Access. Available:

http://lamp.infosys.deakin.edu.au/era/?page=fordet10\&selfor=2001

Le Masurier, M. (2015). What is Slow Journalism?, Journalism Practice, 9 (2): 138-152

Lynch, J. (2010). Peace journalism. In Allan, S. (ed). The Routledge Companion to News and Journalism (pp. 542-553). London: Routledge, 
Lynch, J. \& Galtung, J. (2010) Reporting conflict: new directions in peace journalism. St. Lucia, Qld.: UQP.

Lynch, J. \& McGoldrick, A. (2005). Peace Journalism. Stroud, England: Hawthorn Press.

Miike, Y. (2007). An Asiacentric reflection on Eurocentric bias in communication theory. Communication Monographs, 74(2), 272-278.

Miike, Y. (2014). The Asiacentric turn in Asian communication studies: Shifting paradigms and changing perspectives. In M. K. Asante, Y. Miike, \& J. Yin (Eds.), The global intercultural communication reader (2nd ed., pp. 111-133). New York, NY: Routledge.

Milton, J. (1644). Areopagitica. A speech of Mr John Milton for the liberty of unlicenc'd printing, to the Parliament of England. Hanover, NH: Dartmouth College, : Milton Reading

Room. Available: $<$ http://www.dartmouth.edu/ milton/reading_room/contents/index.shtml $>$

Morison, W. L. \& Sappideen, C. (1989) Torts: Commentary and Materials (7th edn.). Sydney: Law Book Company.

Overington, C. (2009, February 3). DOCS urges fugitive mother to return, The Australian, p. 3. Available: < http://www.theaustralian.com.au/archive/news/docs-urges-fugitive-motherto-return/story-e6frg6o6-1111118737830 > 
Pearson, M., Green, K., Tanner, S. and Sykes, J. (2010). Researching Journalists and Vulnerable Sources - Issues in the Design and Implementation of a National Study. In Pasadeos, Y. (ed) (2010) Advances in Communication and Mass Media Research. Athens: ATINER. pp. 87-96.

Reynolds v. Times Newspapers Ltd [2001] 2 AC 127

Robie, D. (2011). Conflict reporting in the South Pacific - Why peace journalism has a chance, The Journal of Pacific Studies, 31(2): 221-240. Retrieved from: http://www.academia.edu/1374720/Conflict_reporting_in_the_South_Pacific_Why_peace_jo $\underline{\text { urnalism_has_a_chance }}$

Robie, D. (2014). Don't spoil my beautiful face: Media, mayhem and human rights in the Pacific. Auckland, NZ: Little Island Press:

Rolph, D. (2008). Reputation, Celebrity and Defamation Law. Aldershot, UK: Ashgate.

Romano, A.R. (Ed.) (2010) International journalism and democracy : civic engagement models from around the world. New York \& London: Routledge.

Rosen, J. (1999). What Are Journalists For? New Haven, CT: Yale University Press: 
Rosen, J. (2003-2013). PressThink - Ghost of Democracy in the Media Machine. Weblog. Retrieved from http://pressthink.org.

Rupar, V. \& Pesic, M. (2012 ). Inclusive journalism and rebuilding democracy. In In Sakr, N. and Basyouni, H. Rebuilding Egyptian Media for Democratic Future. Cairo Egypt: Aalam El Kootob Publisher

Servaes, J. (Ed.) (2014). Technological determinism and social change: Communication in a tech-mad world. Lanham, MD: Lexington Books.

Servaes, J., Jacobson, T.L. \& White, S.A. (eds.) (1996). Participatory communication for social change. New Delhi \& Thousand Oaks: Sage Publications.

Siebert, F.S., Peterson, T. \& Schramm, W. (1963) Four Theories of the Press. Urbana: University of Illinois Press.

Thanissaro, Bhikkhu (Trans.). (1997). Abhaya Sutta: To Prince Abhaya (On Right Speech) (MN 58). Access to Insight (Legacy Edition). Available at http://www.accesstoinsight.org/tipitaka/mn/mn.058.than.html .

Tolson, A. (2006) Media Talk: Spoken Discourse on TV \& Radio, Edinburgh: Edinburgh University Press. 
Vatican Library (1993), Catechism of the Catholic Church (1993), Citta del Vaticano:

Libreria Editrice Vaticana. Available: <

http://www.vatican.va/archive/ENG0015/_P8K.HTM >.

Waisbord, S. \& Mellado, C. (2014). De-Westernizing communication studies: A reassessment. Communication Theory, 24 (4): 361-72.

Wang, G. (2014). Culture, paradigm, and communication theory: A matter of boundary or commensurability? Communication Theory, 24 (4): 373-93.

Wang, G. \& Shen, V. (2000). East, west, communication, and theory: Searching for the meaning of searching for Asian communication theories. Asian Journal of Communication. 10(2): 14-32.

\section{Cases}

Australian Communications and Media Authority v Today FM (Sydney) Pty Ltd [2015] HCA 7, 4 March 2015 S225/2014. Retrieved from:

https://jade.barnet.com.au/Jade.html\#article=369805

Australian Competition and Consumer Commission (ACCC) v Allergy Pathway Pty Ltd and Anor (No 2) [2011] FCA 74. http://www.austlii.edu.au/au/cases/cth/FCA/2011/74.html 
Clarke v Nationwide News Pty Ltd trading as The Sunday Times [2012] FCA 307 Available:

$<\underline{\text { http://www.austlii.edu.au/au/cases/cth/FCA/2012/307.html }>}$

Grant v. Torstar Corp., 2009 SCC 61, [2009] 3 S.C.R. 640

New York Times Co. v. Sullivan, 376 U.S. 254 (1964)

Today FM (Sydney) Pty Ltd v Australian Communications and Media Authority [2013]

FCA 1157. Available:

http://www.judgments.fedcourt.gov.au/judgments/Judgments/fca/single/2013/2013fca1157 